\title{
Questões de método na análise do telejornalismo: premissas, conceitos, operadores de análise ${ }^{1}$
}

\author{
Itania Maria Mota Gomes² \\ UFBA \\ itania@ufba.br
}

\begin{abstract}
Resumo: Neste artigo, apresentamos questões de método para análise do telejornalismo - a saber, suas premissas, conceitos, operadores de análise. As premissas são de que o telejornalismo é uma instituição social e uma forma cultural. Os conceitos de estrutura de sentimento, gênero televisivo e modo de endereçamento são conceitos metodológicos e devem guiar o exame concreto do telejornalismo, considerado, no primeiro caso, a partir da relação entre elementos dominantes, residuais e emergentes; no segundo, a partir da existência de relações sociais e históricas entre as formas que o telejornalismo assume ao longo do tempo e as sociedades em que essas formas são praticadas; no terceiro, a partir do modo como um programa específico se relaciona com seus telespectadores a partir da construção de um estilo e, ao fazer isso, configura e reconfigura o próprio gênero. Apresentamos os conceitos, buscando explorar seu potencial para a análise. Finalmente, descrevemos os operadores de análise dos modos de endereçamento de programas jornalísticos televisivos: mediador, contexto comunicativo, pacto sobre o papel do jornalismo e organização temática e sua relação com as premissas e conceitos adotados. Nosso esforço foi de construir uma metodologia de análise de telejornalismo a partir da perspectiva teóricometodológica dos cultural studies em associação com os estudos de linguagem, perspectiva que implica a consideração de aspectos históricos, sociais, ideológicos e culturais do telejornalismo.
\end{abstract}

Palavras-chave: telejornalismo, metodologia, estrutura de sentimento, gênero televisivo, modo de endereçamento.

\footnotetext{
${ }^{1}$ Este artigo foi apresentado em encontro do Centre d'Etudes des Images et des Sons Médiatiques/CEISME, Université Sorbonne-Nouvelle, em o5 de abril de 2007.

2 Itania Maria Mota Gomes (itania@ufba.br), Ph.D, é professora do Programa de PósGraduação em Comunicação e Cultura Contemporâneas/UFBA e pesquisadora do CNPq. Realiza pós-doutorado na Université Sorbonne-Nouvelle com bolsa Capes (outubro 2006 a setembro 2007). Coordena o Grupo de Pesquisa de Análise de Telejornalismo, registrado no Diretório de Grupos de Pesquisa do CNPq.
} 
Résumé: Dans cet article, nous présentons des questions de méthode pour l'analyse du journalisme à la télévision - à savoir, leurs prémisses, concepts, opérateurs d'analyse. Les premisses sont telles que le journalisme a la télé est une institution sociale et une forme culturelle. Les concepts de structure de sentiment, genre televisuel et mode d'adresse sont des concepts méthodologiques et doivent guider l'examen concret du journalisme à la télé considérée, dans le premier cas, à partir de la relation entre des éléments dominants, résiduels et émergents; dans le deuxiéme, à partir de l'existence de relations sociales et historiques entre les formes que le journalisme à la télé suppose au long du temps et les sociétés où ces formes sont pratiquées; dans le troisième, à partir de la manière comme un programme spécifique se rapporte avec leurs spectateurs à partir de la construction d'un style et, en faisant cela, configure et reconfigure le genre lui-même. Nous présentons les concepts, en cherchant explorer son potentiel pour l'analyse. Finalement, nous décrivons les opérateurs d'analyse des modes d'adresse des programmes: médiateur, contexte comunicativ, pacte sur le rôle du journalisme et organisation thématique et sa relation avec les prémisses et concepts adoptés. Notre effort a été de construire à une méthodologie d'analyse du journalisme à la télé à partir de la perspective teórique et methodologique des cultural studies en association avec les études du langage, perspective qui implique la considération des aspects historiques, sociaux, idéologiques et culturels du journalisme à la télé.

Mots-clé: journalisme, télévision, methodologie, structure de sentiment, genre televisuel, mode d'adresse.

Abstract: In this article, we namely present questions of method for the analysis of the TV news programs -, its premises, concepts, operators of analysis. The premises are that TV news is a social institution and a cultural form. The concepts of structure of feeling, television genre and mode of address are methodological concepts and must guide the examination of the programs, considered, in the first case, from the relation between dominant, residual and emergent elements; in the second from the existence of social and historical relations between the forms that TV news assumes throughout the time and the societies where these forms are practiced; in the third case, from the way as an specific program relates with its viewers from the construction of a style and, when making this, it configures and reconfigures the genre. We present the concepts, searching to explore its potential for the analysis. Finally, we describe the operators of analysis of the modes of address of TV news programs: mediator, communicational context, pact on the role of the journalism and thematic organization and its relation with the premises and concepts. Our effort was to construct a methodology of analysis of TV news programs from the perspective of cultural studies in association with the studies of language, perspective that implies the consideration of historical, social, ideological and cultural aspects of TV news.

Keywords: TV News, methodology, structure of feeling, television genre, mode of address. 
A importância que a televisão assume no Brasil ainda não produziu, como resultado, o desenvolvimento de métodos de análise adequados de seus produtos. $\mathrm{O}$ mais freqüente é que a televisão seja tomada a partir de abordagens mais gerais, macroeconômicas, históricas ou sociais, e que o programa televisivo, enquanto um produto cultural com certas especificidades, seja deixado de lado. Na maior parte dos casos, os estudos que tomam a televisão como seu objeto de investigação, ainda que considere seus produtos, tendem a se dispersar em direção a outros objetos de análise, afastando-se da análise dos programas efetivamente produzidos e veiculados 3 . No caso do telejornalismo, a situação parece se agravar. Tais estudos têm o mérito de reconhecer a televisão como objeto de interesse científico e de produzir conhecimento relevante sobre a televisão no Brasil, em especial quanto ao seu caráter histórico, social e econômico, mas a pouca ênfase nos produtos televisivos, tomados eles mesmos como objeto empírico, tem resultado numa certa fragilidade teórica e metodológica quando se trata de descrever, analisar, interpretar os modos de funcionamento, as especificidades, as características do programa televisivo.

Nesse artigo, apresentamos algumas questões de método para análise dos programas jornalísticos televisivos. Ele é resultado do esforço de interpretação de diferentes programas telejornalísticos ${ }^{4}$ realizado nos últimos anos e tem como ambição a formulação de uma metodologia de análise de telejornalismo a partir da perspectiva teórico-metodológica dos cultural studies em associação com os estudos de linguagem. Essa abordagem implica a consideração de aspectos ao mesmo tempo históricos, sociais, ideológicos e culturais do telejornalismo e nos permite articular três elementos fundamentais para a análise do telejornalismo, a saber, o jornalismo,

3 No Brasil, algumas exceções são os trabalhos de Vera França, Elizabeth Bastos Duarte, Arlindo Machado, Immacolata Lopes, Maria Carmem Jacob de Souza.

4 No período entre 2001 e 2007, o Grupo de Pesquisa de Análise de Telejornalismo, do PósCom/UFBA, produziu análises de telejornais locais de Salvador (Sampaio, 2005; Borja, 2005, Santos, 2004, Barata, 2006); de programas televisivos esportivos (Silva, 2005); das versões diária e dominical do programa Globo Rural (Maia, 2005), das três versões levadas ao ar, entre 2001 e 2005, do Jornal da MTV (Gutmann, 2005 a), dos programas de entrevista Roda Viva e Gordo a Go-Go (Fernandes, 2005), do Programa Ação, da Rede Globo (SILVA, G. 2005), do Jornal do SBT (Gomes et alii, 2004) e do Jornal Nacional (Gomes et alii, 2005), do Globo Repórter (Pimentel, 2006), do Fantástico (Gomes, L. 2006), dos programas Linha Direta, Brasil Urgente e Cidade Alerta (Duarte, 2007). Atualmente, estão em desenvolvimento pesquisas sobre o Programa do Jô, o Globo Repórter - trabalho cujo corpus inclui dos documentários produzidos nos anos 70 aos programas atualmente veiculados - e de programas jornalísticos populares. 
a televisão e a recepção televisiva. Assumimos como premissa que o telejornalismo é uma forma cultural e uma instituição social, nos termos de Raymond Williams. A partir dessas premissas, articulamos os conceitos de estrutura de sentimento, gênero televisivo e modos de endereçamento, que são aqui tomados como conceitos metodológicos, ou seja, como instrumentos para trabalhar materiais empíricos. Finalmente, apresentamos os operadores de análise dos modos de endereçamento que desenvolvemos no trabalho analítico.

\section{Premissas: o telejornalismo como instituição social e como forma cultural 5}

Considerar o telejornalismo na perspectiva dos estudos culturais deve implicar articular suas dimensões técnica, social e cultural, o que garante unidade ao nosso objeto de estudo e um olhar mais atento ao analista. Do nosso ponto de vista, isso significa acompanhar Raymond Williams, para quem a televisão é, ao mesmo tempo, uma tecnologia e uma forma cultural, e o jornalismo, uma instituição social (1997, p. 22) ${ }^{6}$.O telejornalismo é, então, uma construção social, no sentido de que se desenvolve numa formação econômica, social, cultural particular e cumpre funções fundamentais nessa formação. A concepção de que o telejornalismo tem como função institucional tornar a informação publicamente disponível e de que o que faz através das várias organizações jornalísticas é uma construção: é da ordem da cultura e não da natureza do jornalismo ter se desenvolvido deste modo em sociedades específicas. Michael Schudson (1978), numa análise histórica da imprensa norte-americana, e em especial do conceito de objetividade, evidencia como o jornalismo vai se construindo como instituição social específica em relação com o contexto histórico, social,

\footnotetext{
5 Embora com outros objetivos, parte da discussão apresentada neste item foi desenvolvida em GOMES, 2006b.

${ }^{6}$ Para Williams, as instituições são um dos três aspectos de todo processo cultural, junto com as tradições e as formações (1971, p. 118 ss). Ali, os meios de comunicação aparecem, junto com a família, a escola, a igreja, certas comunidades e locais de trabalho, como instituições que exercem poderosas pressões sobre o modo de vida, "ensinam, confirmam e, na maioria dos casos, finalmente impõem significados, valores e atividades”. No entanto, não é possível dissociar a análise das instituições da análise das tradições ("a expressão mais evidente das pressões e limites dominantes e hegemônicos") e das formações (esses movimentos e tendências efetivos que têm significativa influência no desenvolvimento ativo de uma cultura). Nesse sentido, as instituições seriam, então - e no sentido que esses termos adquirem no pensamento de Raymond Williams - constituídas e constituintes e se devem ser pensadas na relação com as tradições e formações.
} 
econômico dos Estados Unidos. Por exemplo, antes de 1830 a objetividade não era uma premissa. Ao contrário, esperava-se que o jornalismo assumisse um ponto de vista e não que se apresentasse como um relato neutro ou imparcial. O telejornalismo, como instituição social, não se configura somente a partir das possibilidades tecnológicas oferecidas pelos séculos anteriores, mas na conjunção das possibilidades tecnológicas com determinadas condições históricas, sociais, econômicas e culturais. Isso de modo algum significa conceber o jornalismo como cristalização, mas, bem ao contrário, afirmar seu caráter de processo histórico e cultural.

Afirmar o telejornalismo como uma construção, no entanto, e justamente por esta razão, não nos impede de reconhecer que ele se configura como uma instituição social de certo tipo nas sociedades ocidentais contemporâneas. No Brasil, em que o jornalismo supostamente reproduziria o modelo de jornalismo independente estadunidense, pensar o jornalismo como instituição social requer colocar em causa a relação entre jornalismo e a noção habermasiana de esfera pública 7, com suas implicações sobre a noção de debate público e vigilância pública; a perspectiva liberal sobre o papel democrático da mídia; a noção de quarto poder, em que está implícita a autonomia da imprensa em relação ao governo, o direito à liberdade de expressão e o compromisso com o interesse público; o caráter público ou privado da empresa jornalística.

Pensando sobre as conseqüências do "dilúvio comercial" sobre o sistema midiático europeu, Blumler \& Gurevitch (1995) partem da teoria da democracia, pensada aos moldes da democracia representativa, para descrever as funções e serviços que os media cumpririam no sistema político. Para esses autores, os media teriam por função a vigilância sobre o sistema social e político, o estabelecimento de uma agenda pública, a disponibilização de uma plataforma para a defesa esclarecida de causas e interesses de grupos, o diálogo entre diferentes pontos de vista e entre esses pontos de vista e o público massivo, mecanismos de prestação de contas para quem exerce o poder público, incentivos para que os cidadãos aprendam, escolham e se envolvam com o processo político, resistência aos efeitos das forças externas aos

7 Ver GOMES, W. 1998; JENSEN, 1986 (p.31 ss). 
media para subverter sua independência, integridade e capacidade de servir ao interesse público, respeito pelos membros da audiência como preocupados e capazes de compreender seu ambiente político.

Essas premissas implicam também uma específica concepção de notícia ou de informação jornalística. É nesse modelo de jornalismo que as noções de imparcialidade e objetividade fazem sentido. É neste modelo de jornalismo que as distinções entre fato e ficção, informação e entretenimento tornam-se úteis. É claro que, na nossa concepção, a notícia é uma construção e não uma representação "fiel" da realidade. As noções de objetividade e imparcialidade no jornalismo são mais apropriadas a uma concepção empiricista da realidade que está fora do enquadramento da nossa perspectiva teórica. É certo que a objetividade é construída e tem uma hereditariedade comercial (Shudson, 1978; Dayan, 2005), entretanto, ambas as noções são úteis na análise porque enquadram o modo como o jornalismo é socialmente aceito, e regulam, pelo menos retoricamente, as ações profissionais e as expectativas do público.

Embora assuma uma concepção de jornalismo como mediação, que se coloca mesmo em oposição à perspectiva construtivista e culturalista que assumimos aqui, a descrição que Josenildo Guerra (2003) faz do processo de produção jornalística nos é útil porque oferece os parâmetros através dos quais o jornalismo brasileiro contemporâneo se configura como uma instituição social e, em conseqüência, os parâmetros com que lidam os jornalistas, as instituições jornalísticas e os receptores no processo de produção de sentido do jornalismo.

É nesse sentido que pode ser útil tomar em consideração, para a análise do telejornalismo, os elementos que configuram o percurso interpretativo na produção da notícia. Guerra define este percurso como o processo efetivamente "levado a cabo pelo jornalista, no qual ele parte de um problema ou fato inicial que será objeto de apuração, desenvolve ações com vistas a ‘solucioná-lo', até chegar a um entendimento final a ser expresso na forma de notícia" (Guerra, 2003, p.164). E propõe analisá-lo a partir de dois tipos de técnicas, as técnicas cognitivas do processo, ou seja, o conjunto de saberes relativos à natureza do fazer, ao como fazer e às circunstâncias do fazer jornalístico, e as técnicas cognitivas de conteúdo, que dizem respeito à interpretação 
dos fatos que são objeto do jornalismo. A natureza do fazer define o próprio conceito de jornalismo numa determinada sociedade e o configura como uma instituição social. O como fazer diz respeito à perícia, à competência para efetivação do processo de produção da notícia. As circunstâncias do fazer se referem às condições empíricas nas quais o jornalismo se realiza e diz respeito aos constrangimentos econômicos, políticos, técnicos, sociais, ou, como diz o autor, se referem às esferas de convivência que tornam o jornalismo também um fazer possível. "É somente porque o como fazer e o fazer possível satisfazem o dever fazer presumido que uma atividade pode ser considerada jornalística e, conseqüentemente, submeter-se às necessárias avaliações de desempenho" (Ibidem, p. 192). Em outras palavras, é o modo como o jornalismo se configura como instituição social de certo tipo, numa dada sociedade, que regula o julgamento sobre a sua qualidade.

As técnicas cognitivas de conteúdo definem para o jornalista o que será objeto do processo de produção da notícia, e implicam uma abertura em relação ao fato (o conhecimento das áreas temáticas de cobertura noticiosa) e em relação aos indivíduos (conhecimento das expectativas dos receptores). A abertura para os indivíduos evidencia a perspectiva propriamente comunicacional do jornalismo e se define de modo mais específico como os valores-notícia de uma determinada sociedade, num momento histórico específico. Os valores-notícia se referem duplamente às expectativas da sociedade (e, por conseqüência, dos receptores de um dado veículo) e à responsabilidade social do jornalismo (que, no modelo de jornalismo que adotamos tem a ver com a noção de compromisso com o interesse público e com as prerrogativas básicas para o exercício profissional, a liberdade de expressão e de informação).

No entanto, chamamos a atenção, para os nossos propósitos, de que Guerra faz uma interessante distinção entre valor-notícia e valor-notícia de referência. Os valores-notícia, como dissemos, caracterizam as expectativas de uma dada sociedade. Os valores-notícia de referência são aqueles que orientam o fazer jornalístico de uma determinada organização jornalística, dizem respeito ao modo como uma organização compatibiliza as diretrizes institucionais com as demandas da sua audiência. Valor-notícia, aqui, não é o mesmo que é comumente reconhecido na 
bibliografia jornalística como critérios organizacionais de noticiabilidade, pois enquanto estes são critérios internos à organização, à sua estrutura de trabalho, aqueles se voltam para uma justificativa externa à organização e se vinculam ao jornalismo como instituição social.

Chamamos a atenção de que essas premissas sobre o jornalismo precisam ser analisadas em relação ao contexto profissional e cultural em que a prática jornalística acontece. Embora, em termos gerais, possamos imaginar que certos cânones e expectativas sejam próprios de sociedades contemporâneas, há diferenças marcantes em relação à história do jornalismo e dos media em cada contexto específico (por exemplo, para indicar apenas as mais discutidas, as diferenças entre os modelos inglês e norte-americano de televisão e de jornalismo) e de modo algum concordamos em que não há diferenças - de práticas, de sistema, de ideologia - no jornalismo realizado em distintos períodos históricos e distintas sociedades. Até certo ponto, muitos dos valores e normas profissionais adotados pelos jornalistas em países democráticos são 'made in the USA'. No entanto, devemos nos perguntar como esses valores e normas são efetivamente desenvolvidos nas atividades profissionais específicas e como eles configuram produtos comunicacionais específicos em diferentes contextos ${ }^{8}$.

Do nosso ponto de vista, um dos principais desafios da investigação sobre o jornalismo contemporâneo é compreender como duas questões centrais do nosso século, a tecnologia digital e o multiculturalismo ou, se quisermos dizer de outro modo, os largos processos de globalização e os fluxos migratórios, interagem com o jornalismo e que implicações têm sobre o jornalismo enquanto uma atividade social, enquanto ideologia e enquanto campo profissional. Do ponto de vista dos valores que constituem o jornalismo como instituição social, é fundamental interrogar como se dá a conjunção entre jornalismo, sociedade e cultura, como essa conjunção interage

\footnotetext{
${ }^{8}$ Afonso de ALBUQUERQUE analisa a influência do modelo jornalístico estadunidense sobre o jornalismo brasileiro e chama a atenção para o fato de que os diferentes ambientes político e cultural em que os dois jornalismos se configuram deveriam fazer supor que o modelo de jornalismo efetivamente praticado também difere. Segundo o autor, é de se supor que a adesão dos jornalistas brasileiros aos princípios do jornalismo estadunidense "é antes de tudo um gesto formal; na prática, os jornalistas brasileiros tendem a interpretar esses princípios e a definir o seu compromisso político de maneira muito diferente dos seus colegas americanos" (1999, p.9).
} 
com e reconfigura certos valores jornalísticos tomados como universais: serviço público, objetividade, atualidade, credibilidade, independência, legitimidade ${ }^{9}$.

A noção de serviço público, por exemplo, é um dos principais valores jornalísticos. A ela se recorre para argumentar a favor da própria legitimidade do jornalismo e a ela está associada a noção de interesse público, que parece regular a prática profissional. Não seria o caso de perguntarmos se a diversidade cultural, no modo como ela é vivenciada atualmente no contexto europeu, para falarmos de apenas um exemplo em que essa situação é mais evidente, não implicaria uma modificação na noção de interesse público nessas sociedades? Nessas sociedades, a questão da imigração - a relação com as identidades culturais, mas também com o desemprego e a violência - tem aparecido no centro de várias disputas políticas (Inglaterra, França Itália, Alemanha ), mas tem implicado também uma redefinição do jornalismo em direção ao reconhecimento da diversidade cultural desses países ou, quando menos, um recrudescimento da crítica ao modo como os jornalistas e os veículos enquadram a diferença cultural. De todo modo, isso parece demandar um olhar culturalmente mais diversificado, com implicações sobre o processo de decisão editorial ${ }^{10}$. A importância dos processos de globalização e diversidade cultural para o jornalismo diz respeito ao conhecimento que os jornalistas têm ou precisarão ter sobre as diferentes culturas e etnias, às questões da representação e, particularmente, à percepção da responsabilidade social dos jornalistas - e do jornalismo como instituição - em sociedades democráticas e multiculturais (cf. Deuze, 2005, p. 453).

Ao mesmo tempo em que a convergência tecnológica implica uma reorganização do processo de produção jornalística, com conseqüências sobre o que costumamos chamar de cultura jornalística, as tecnologias digitais têm favorecido, senão o surgimento, a consolidação do jornalismo de tipo cidadão, com a proliferação

\footnotetext{
9 Mark DEUZE (2005) realiza um interessante estudo sobre as implicações das novas tecnologias e da diversidade cultural sobre a configuração da ideologia jornalística, indicando sutis e lentas transformações na concepção dos valores de serviço público, objetividade, imediaticidade, autonomia e ética.

10 BERKOWITZ; LIMOR \& SINGER (2004) propõem um olhar intercultural sobre a noção de interesse público e estudam como jornalistas estadunidenses e israelenses se comportam em relação a determinadas questões éticas relativas à prática profissional. Segundo os autores, "as diferenças nacionais fortes parecem impossibilitar todas as percepções ou valores jornalísticos universais” (p.164).
} 
dos recursos de interatividade, dos blogs, chats, do jornalismo open source e de sites de disponibilização de videos que tendem a reconfigurar os valores jornalísticos e a relação entre jornalismo e público. No caso específico do telejornalismo, verificamos, por exemplo, que cada vez mais as grandes emissoras têm utilizado imagens de amadores, em particular de filmes produzidos com telefones celulares - imagens, portanto, que não seguem quaisquer dos critérios profissionais de controle e verificação da informação - como modo justamente de ampliar a autenticidade e a veracidade dos programas telejornalísticos.

De modo imbricado com suas configurações como instituição social, o jornalismo se configura também como uma forma cultural. No caso do telejornalismo, acreditamos que, para entendê-lo, é preciso compreender a notícia como uma forma cultural específica de lidar com a informação e o programa jornalístico televisivo como uma forma cultural específica de lidar com a notícia na TV. Queremos fazer ver que, apesar de ser um gênero fortemente codificado, se sua história tivesse sido outra, o telejornal poderia ter hoje outro formato (cf. Machado, 2000, p. 105). Abordaremos a notícia como um gênero do discurso e o programa jornalístico televisivo como um gênero midiático.

A notícia é discurso e, como tal, um conjunto de convenções que ajudou a configurar o jornalismo como uma instituição socialmente reconhecida e no interior do qual fazem sentido as noções de imparcialidade e objetividade e as distinções entre fato e ficção, informação e entretenimento. Naturalmente, a notícia televisiva é um discurso que é estruturado pelos discursos mais amplos da televisão. A notícia, seja ela ouvida no rádio, lida nos jornais ou vista na televisão, ganha muito de sua configuração das características do próprio meio no qual ela aparece. Daí a importância de analisarmos as configurações da notícia como um gênero discursivo em relação às características que ela ganha quando elaborada para transmissão na televisão.

Klaus Bruhn Jensen entende que "um gênero é uma forma cultural que apresenta a realidade social em uma perspectiva própria e, ao fazer isso, implica formas específicas de percepção e usos sociais do conteúdo. Assim, o gênero 
estabelece um modo de comunicação ou, mais especificamente, uma situação comunicativa, entre o emissor e o destinatário" (Jensen, 1986, p.50). Seguindo Raymond Williams (1979), Jensen propõe que a definição da notícia como um discurso leve em conta três aspectos, a posição, o assunto adequado e o modo de composição formal ${ }^{11}$.

Com posição do autor em relação ao seu material, que na literatura tem sido tradicionalmente definida como narrativa, dramática e lírica, os autores se referem a um modo de organização básica que determina um tipo particular de apresentação dos conteúdos. A posição tem a ver não apenas com o modo como o autor aborda um tema, mas também com os objetivos retóricos daquela abordagem em relação à audiência. O que o conceito de posição enfatiza é que qualquer texto é sempre uma comunicação socialmente situada.

No caso do gênero notícia, a posição que é projetada enfatiza o papel do jornalista como um observador independente, sua apuração dos fatos sociais, a contraposição de pontos de vista e assim por diante. Simultaneamente, o leitor/telespectador é posicionado como um receptor de informações reais, confiáveis, presumivelmente relevantes num sentido político mais amplo (Jensen, 1986, p. 50).

O tema apropriado de diferentes gêneros varia enormemente. O tema do gênero notícia, por exemplo, no modelo de jornalismo que conhecemos, deriva da noção de esfera pública e sua implícita separação das esferas sociais. John Hartley (2001, p. 38-39) sugere que ainda que esperemos que as notícias sejam sobre os acontecimentos sociais mais relevantes, o que temos, de fato, é uma categorização que antecipadamente enquadra esses acontecimentos: política, economia, política externa, acontecimentos locais, esportes e o que ele chama de histórias ocasionais (fait divers, notícias sobre celebridades etc.). Essa categorização constrói um quadro conceitual em que os eventos são interpretados e é um dos principais mecanismos de controle da produção de sentido que encontramos nos telejornais: "percebemos e interpretamos o mundo em termos parcialmente derivados das classificações que se tornaram familiares no jornalismo" (Hartley, 2001, p. 5).

\footnotetext{
${ }^{11}$ Williams e Jensen falam em stance, the appropriate subject matter e mode of formal composition. Aqui adotamos os termos tal como apresentados na tradução de Marxismo e Literatura, publicado no Brasil pela Zahar.
} 
A notícia tem um modo de composição formal característico: cabeça - off passagem - sonoras e nota pé. A notícia tende a ter uma composição regular e característica.

A posição, o assunto adequado e o modo de composição formal da notícia como um gênero são configurados historicamente e podem ser compreendidos, segundo Jensen, a partir dos seguintes aspectos: a notícia como forma de conhecimento, a notícia como comunicação, os critérios de noticiabilidade e a estrutura da notícia, aos quais ele acrescenta aqueles que seriam mais específicos da notícia televisiva, a imagem e o que o autor chama de formato. Por formato, o autor se refere ao fato de que os programas jornalísticos organizam as informações através do recurso a um apresentador que, através da tela, se endereça diretamente à audiência. Ao fazer isso, o apresentador funciona como uma força unificadora, que integra as diferentes histórias num fluxo coerente.

No telejornalismo, o componente da imagem faz muita diferença. Jensen coloca ênfase na questão da credibilidade, de como as imagens da cobertura televisiva reforçam a expectativa de objetividade e imparcialidade, e nas convenções jornalísticas que regulam a imagem jornalística. A variedade de imagens oferecidas aparece também como um forte apelo para a audiência e, de modo a manter o telespectador preso no fluxo televisivo, no telejornalismo as imagens são estruturadas de acordo com a estética de produção de mercadoria. Além disso,

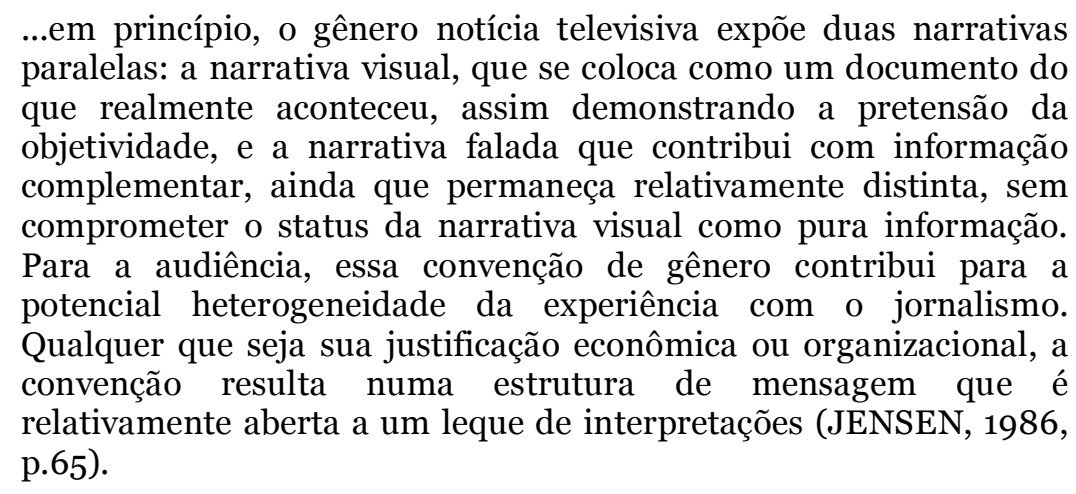

Considerar o telejornalismo como instituição social e como forma cultural implica que a análise de todo e qualquer produto telejornalístico demanda uma forte contextualização: contextualização do programa na grade de programação da 
emissora, contextualização do programa em relação à emissora, entendida enquanto marca e enquanto organização jornalística, contextualização em relação à concorrência, contextualização em relação à televisão e em relação ao jornalismo, contextualização em relação à sociedade e à cultura. Essa contextualização não deve ser um pretexto para abandonarmos o programa televisivo ele mesmo em prol de uma análise que, embora tome o programa como ponto de partida, rapidamente se volta para outros objetos. A contextualização deve ter como objetivo compreender o programa como produto cultural específico, enquanto conjunto de estratégias histórica, econômica, cultural, ideológica e socialmente marcadas. A contextualização, para os fins que nos interessam aqui, não se transforma no objeto de investigação, mas deve nos ajudar a melhor compreender o objeto - o programa. Analisar o contexto em que um programa se insere deve significar, no esforço mesmo de análise, verificar como um programa específico apela, faz referência a, convoca seu contexto. Em outros termos, quando analisamos um programa - por exemplo, o Linha Direta, da Rede Globo ${ }^{12}$ - devemos nos perguntar em que Brasil esse programa é possível, em que jornalismo e em que sociedade podemos tão facilmente passar da factualidade à dramaturgia, em que emissora um programa jornalístico pode incorporar tão naturalmente o uso de atores, os enquadramentos e planos da telenovela, como um programa televisivo se constrói na relação, ao mesmo tempo, com os gêneros televisivos e com o gênero policial, ou seja, como convoca uma certa competência cultural dos seus receptores em relação ao gênero policial - no cinema, na literatura.

Propomos que essa análise deva ser marcadamente histórica, ou seja, que ela se dê na consideração de uma história cultural da televisão - é preciso que a análise de um programa observe como ele se inscreve no contexto histórico, técnico, econômico, social, cultural de formação da televisão em uma determinada sociedade e do momento específico em que o programa em questão é transmitido - e de uma história cultural do jornalismo - nesse caso, é preciso tomar em consideração na análise como valores e normas que configuram o jornalismo e as expectativas sociais sobre o jornalismo tomam corpo em um programa telejornalístico específico, como

${ }^{12}$ http://linhadireta.globo.com/. Ver Duarte, D. 2006. 
esse programa atualiza essas normas e valores jornalísticos socialmente reconhecidos. É em relação a esse contexto também que se torna importante considerar como concepções de jornalismo se relacionam com concepções sobre a sociedade (sobre sua economia, suas instituições, as relações de poder, suas formas de pensamento).

\section{Os conceitos: Estrutura de Sentimento, Gênero Televisivo e Modo de Endereçamento}

Estrutura de Sentimento, Gênero Televisivo e Modo de Endereçamento são tomados aqui como conceitos metodológicos, ou seja, eles devem encontrar sua melhor perspectiva através de estudos em que sejam usados como instrumento para trabalhar materiais empíricos - colocando-lhes questões e organizando sua observação (cf.Braga, 1997). Os três conceitos têm em comum sua origem - nasceram do esforço da análise cultural - e sua preocupação com o sujeito, com o processo ativo de produção de sentido na cultura. Nesse sentido, em diferentes estágios ou níveis, eles colocam atenção sobre os receptores e a recepção.

Estrutura de sentimento é um conceito que habilita o analista a estar atento aos significados e deslocamentos de significados que as palavras-chave que definem o jornalismo como instituição - objetividade, imparcialidade, verdade, relevância, pertinência, factualidade, interesse público, responsabilidade social, liberdade de expressão, atualidade, quarto poder, para dizer apenas algumas - adquirem. Nesse sentido, ele permite um olhar para o processo, para o modo como o telejornalismo é construído processualmente e, assim acessar a emergência de novas características que ainda não se cristalizaram em ideologias, convenções, normas, gêneros. A adoção do conceito de gênero televisivo deve possibilitar ao analista o reconhecimento da existência de relações sociais e históricas entre determinadas formas culturais - no nosso caso, os programas jornalísticos televisivos - e as sociedades e períodos nos quais essas formas são praticadas. Ele permite compreender as regularidades e as especificidades em produtos que se configuram historicamente - ele permite dizer tanto do jornalismo como ideologia, valores, normas, quanto das formas culturais historicamente dadas - e, sobretudo, vincular nosso objeto de análise ao processo comunicacional -gênero televisivo é uma estratégia de comunicabilidade. Modo de 
endereçamento, na medida em que diz do modo como um determinado programa se relaciona com sua audiência a partir da construção de um estilo, deverá permitir ao analista compreender como essas questões são atualizadas em um produto específico, objeto da análise. Em seguida, apresentamos cada um dos conceitos, buscando evidenciar seu potencial metodológico.

\section{Estrutura de Sentimento}

Metodologicamente, estrutura de sentimento é apresentada por Raymond Williams como uma hipótese cultural que nos permitiria estudar a relação entre os diferentes elementos de um modo de vida ${ }^{13}$. O conceito aparece pela primeira vez em The Long Revolution, no capítulo dedicado à análise da cultura, e continuará a ser trabalhado por Williams até Marxismo e Literatura, em que aparece como um capítulo autônomo dentro da parte dedicada à teoria cultural. Depois disso, o conceito será abandonado pelo autor, apesar de seu potencial teórico-metodológico. Do ponto de vista do que nos interessa aqui, acreditamos que estrutura de sentimento poderá ser útil à compreensão e à abordagem do jornalismo como instituição social: permite olhar para o que é socialmente instituído como normas, valores, convenções do campo e o que é vivido, o que é a prática cotidiana e o que ela

\footnotetext{
$13 \mathrm{O}$ conceito de cultura como modo de vida é desenvolvido por Willliams em Culture and Society. Para o autor, a idéia de cultura como um modo inteiro de vida vem mostrar que a mudança social nunca é parcial: a alteração em qualquer elemento de um sistema complexo afeta seriamente o conjunto. Naquele momento, Williams estava em busca de uma teoria cultural que permitisse abordar aquilo que lhe parecia ser uma questão fundamental: a cultura da classe trabalhadora; e somente um conceito largo de cultura, que não reduzisse a cultura a seus artefatos ou a um corpo de trabalho imaginativo permitiria isso. Já que a classe trabalhadora, por sua própria posição, não produziu uma cultura no sentido mais estrito, caberia então buscar uma formulação que permitisse considerar outras contribuições da classe trabalhadora. E Williams encontra: o que a classe trabalhadora produziu foi todo um modo de vida. Esse conceito adquire com o marxismo uma maior envergadura: modo de vida não implica apenas a forma de morar, a maneira de vestir ou de aproveitar o lazer; implica, sobretudo, formas de conceber a natureza da relação social. Pensar a cultura como um modo de vida e, sobretudo, colocar o centro do seu interesse na cultura da classe trabalhadora permite aos Estudos Culturais rejeitar a idéia de uma cultura de massas e o próprio conceito de massa que lhe dá sustentação. Em conseqüência, atinge-se também a idéia de manipulação das massas, que era então o termo chave com o qual se explicava a relação do homem com a cultura e a comunicação contemporâneas. Implica, também, recusar a idéia correlata de uma cultura sem classe.
} 
contém de características e qualidades que ainda não se cristalizaram em ideologias e convenções.

Estrutura de sentimento é um termo difícil. Com ele Williams quer se referir a algo "tão firme e definido como sugere a palavra 'estrutura', ainda que opere nos espaços mais delicados e menos tangíveis de nossa atividade" (1961, p. 48). "Sentimento" aparece aí para marcar uma distinção em relação aos conceitos mais formais de visão de mundo ou ideologia, para dar conta de significados e valores tais como são vividos e sentidos ativamente, levando em consideração que "as relações entre eles e as crenças formais ou sistemáticas são, na prática, variáveis (inclusive historicamente variáveis), em relação a vários aspectos” (1971, p. 134), enquanto "estrutura" quer chamar a atenção para elementos que se apresentam "como uma série, com relações internas específicas, ao mesmo tempo engrenadas e em tensão". De todo modo, estrutura de sentimento se refere a uma experiência social que está em processo ou em solução, com freqüência ainda não reconhecida como social. Com ele, Williams pensa poder acessar a emergência de novas características que ainda não se cristalizaram em ideologias, convenções, normas, gêneros.

Admitimos que o conceito é difícil, que apresenta problemas na sua formulação e na sua operacionalização, mas acreditamos que ele é um conceito-chave no pensamento de Williams e tem forte potencial metodológico e teórico.

Beatriz Sarlo (1997) propõe articular estrutura de sentimento com as noções de dominante, residual e emergente que Williams utiliza em Marxismo e Literatura para descrever elementos de diferentes temporalidades e origens que configuram o processo cultural. Segundo Williams, é claro que a análise cultural deve considerar as características dominantes de um determinado processo ou sistema cultural, mas o analista precisa estar atento também a um certo senso de movimento, de processo histórico, e às articulações e inter-relações complexas entre esses elementos dominantes e os residuais, aqueles elementos que foram efetivamente formados no passado, mas ainda estão ativos no processo cultural, não só como elemento do passado, mas como um elemento efetivo do presente, e emergentes, novos significados e valores, novas práticas, novas relações e tipos de relação que são efetivamente criados e que aparecem como substancialmente alternativos ou opostos 
na cultura dominante. Segundo o autor, é "com as formações emergentes que a estrutura de sentimento, como solução, se relaciona" (1971, p. 136):

o que temos de observar é, com efeito, uma emergência preliminar, atuante e pressionante, mas ainda não perfeitamente articulado... É para compreender melhor essa condição de emergência preliminar, bem como as formas mais evidentes do emergente, do residual e do dominante, que devemos explorar o conceito de estruturas de sentimento (1971, p. 129).

Trabalhar com a hipótese cultural da estrutura de sentimento impede olhar o telejornalismo apenas como cristalização, impede também observá-lo como unidimensional, mas, ao contrário, favorece recuperar as fissuras, as ranhuras das práticas jornalísticas culturalmente vividas. Nesse sentido, se acolhemos estrutura de sentimento como um conceito metodológico, o jornalismo não poderá nunca ser considerado, para fins da análise, como uma "escola", como uma instituição claramente e indefinidamente estadunidense ou anglo-saxônica que se espalha pelo mundo global - existirão tantos jornalismos quantas são as culturas, as sociedades e os tempos históricos em que ele é praticado e o trabalho do analista é encontrar as marcas da sua heterogeneidade constitutiva, a co-presença, em seus produtos, de elementos dominantes, residuais e emergentes.

Ao longo de todo o seu trabalho de configuração de uma teoria da cultura e de uma história cultural da arte e da comunicação, Williams vai buscar compreender as articulações entre os elementos dominantes, residuais e emergentes através da história das palavras e idéias.

Williams pensava que, nos deslocamentos e na acumulação de sentidos operados nas palavras-chave, podiam ser lidos, como se a língua fosse o suporte histórico de um mapa cultural, os avatares da mudança nas instituições políticas e sociais bem como os das relações entre elas e as práticas culturais (SARLO, 1997, p. 93).

Para os fins que nos interessam aqui, de configuração de uma metodologia de análise de programas jornalísticos televisivos, não se trata de ocupar o analista com a historiografia das palavras que constituem o jornalismo. Trata-se, antes, de estar atento ao trabalho dos historiadores do jornalismo e de, na análise de produtos concretos, observar os significados e deslocamentos de significados que as palavraschave que definem o jornalismo como instituição - objetividade, imparcialidade, 
interesse público, responsabilidade social, liberdade de expressão, atualidade, quarto poder, para dizer apenas algumas - adquirem.

\section{Gênero televisivo}

Há algum tempo vimos tentando fazer dialogar os estudos culturais e os estudos da linguagem assumindo como ponto de convergência a discussão sobre os gêneros - discursivos, textuais, literários - e a possibilidade de articulação de uma teoria dos gêneros televisivos ${ }^{14}$. Falando a propósito dos gêneros literários, Raymond Williams afirma que uma discussão sobre o gênero supõe o reconhecimento de dois fatos:

Primeiro, a existência de relações sociais e históricas claras entre determinadas formas literárias e as sociedades e os períodos nos quais foram originadas ou praticadas; segundo, a existência de continuidades indubitáveis nas formas literárias através e além de sociedades e períodos com os quais têm essas relações. Na teoria dos gêneros, tudo depende do caráter e processo dessas continuidades (Williams, 1979, p. 182).

Reconhecemos, com Williams, a existência de relações sociais e históricas entre determinadas formas culturais e as sociedades e períodos nos quais essas formas são praticadas. Reconhecemos, igualmente, que um gênero é um modo de situar a audiência televisiva, em relação a um programa, em relação ao assunto nele tratado e em relação ao modo como o programa se destina ao seu público. No entanto, acreditamos que podemos avançar numa teoria dos gêneros e na avaliação de programas jornalísticos televisivos se adotarmos a concepção de gênero televisivo ou gênero midiático ${ }^{15}$, concepção sustentada pela ênfase no processo comunicacional instaurado por uma determinada forma cultural:

a análise dos processos midiáticos em sua categorização por gênero repousa sobre a idéia de que tanto os produtos quanto os processos de recepção desses produtos são elementos interdependentes do processo de produção de sentido dos discursos sociais ligados ao fenômeno midiático (JANOTTI JR, 2005, p.3).

\footnotetext{
14 Ver GOMES. 2002.

15 Para uma discussão dos conceitos de gênero do discurso, gênero textual e gênero midiátivo, ver JANOTTI JR., 2005.
} 
Nessa perspectiva, gênero é uma estratégia de interação e investir numa abordagem dos gêneros televisivos significa ultrapassar a dicotomia entre análise do produto televisivo e análise dos contextos sociais de sua produção ou de sua recepção. Ao mesmo tempo, significa, na atenção aos estudos da linguagem, ultrapassar a noção de decodificação dos textos (massivos), ou de uma semiótica dos códigos, de uma análise interna ou imanente da obra e pensar em noções mais próximas de uma pragmática da comunicação.

Nesse sentido, colocar a atenção nos gêneros televisivos implica reconhecer que o receptor orienta sua interação com o programa e com o meio de comunicação de acordo com as expectativas geradas pelo próprio reconhecimento do gênero.

O gênero não é algo que passa ao texto, mas algo que passa pelo texto... O gênero é uma estratégia de comunicação, ligada profundamente aos vários universos culturais...O gênero não é só uma estratégia de produção, de escritura, é tanto ou mais uma estratégia de leitura (BARBERO, 1995, p. 64).

Os gêneros são formas reconhecidas socialmente a partir das quais se classifica um produto midiático. Em geral, os programas individualmente pertencem a um gênero particular, como a ficção seriada ou o programa jornalístico, na TV, e é a partir desse gênero que ele é socialmente reconhecido. No caso da recepção televisiva, por exemplo, os gêneros permitem relacionar as formas televisivas com a elaboração cultural e discursiva do sentido.

Os programas telejornalísticos são, então, considerados como uma variação específica dentro da programação televisiva, enquanto compondo, no seu conjunto um gênero - programa jornalístico televisivo, que obedece a formatos e regras próprias do campo jornalístico em negociação com o campo televisivo. Os telejornais, programas de entrevistas, documentários televisivos, as várias formas de jornalismo temático (esportivos, rurais, musicais, econômicos) são variações dentro do gênero: podemos chamá-los subgêneros ou formatos (cf. Bastos, 2004). E demandam ser abordados em categorias que impliquem considerá-los, ao mesmo tempo, como um produto de jornalismo televisivo - o que implica uma abordagem que leve em conta a linguagem televisiva e os elementos próprios do campo jornalístico - e como um produto comunicacional - o que implica uma abordagem da interação como os 
telespectadores. Por outro lado, o telejornalismo é também um produto cultural contemporâneo, marcado social, histórica, econômica e politicamente e participa, no dizer de Stuart Hall (1997), do circuito da cultura - o que implica uma abordagem que leve em conta os modos como os programas jornalísticos constroem e representam a cultura.

É na articulação, portanto, entre os elementos próprios da linguagem televisiva, do fazer jornalístico e da representação da cultura que acreditamos que se dê a configuração de um gênero ou subgênero específico dentro da programação televisiva e, em conseqüência, os modos como ele, enquanto uma estratégia de comunicabilidade ou estratégia de interação, se endereça aos seus receptores.

O gênero televisivo, no entanto, é algo da ordem da virtualidade (Bastos, 2004, p.67), ou seja, não podemos encontrar por aí um exemplar puro de um gênero. Como virtualidade, entretanto, o gênero encontra sua realização em programas específicos e, no sentido que adotamos aqui, nos modos de endereçamento que cada programa constrói na relação com os receptores.

\section{Modo de endereçamento}

O conceito de modo de endereçamento surge na análise fílmica, especialmente aquela vinculada à screen theory e tem sido, desde os anos 80, adaptado para interpretação do modo como os programas televisivos constroem sua relação com os telespectadores ${ }^{16}$. Modo de endereçamento é aquilo que é característico das formas e práticas comunicativas específicas de um programa, diz respeito ao modo como um programa específico tenta estabelecer uma forma particular de relação com sua audiência (cf. Morley \& Brunsdon, 1978). A análise do modo de endereçamento associada ao conceito de gênero televisivo deve nos possibilitar entender quais são os formatos e as práticas de recepção solicitadas e historicamente construídas pelos programas jornalísticos televisivos. Na nossa perspectiva, o conceito de modo de endereçamento tem sido apropriado para ajudar a

\footnotetext{
${ }_{16}$ Para uma discussão mais detalhada do conceito de modo de endereçamento, sua vinculação à screen theory e as atualizações elaboradas pelos cultural studies, em especial pelos estudos de recepção, ver GOMES, 2006.
} 
pensar como um determinado programa se relaciona com sua audiência a partir da construção de um estilo, que o identifica e que o diferencia dos demais.

Autores como David Morley (1978, 1999), John Hartley (1997, 2000, 2001) e Daniel Chandler (2003) articulam os modos de endereçamento para compreender a relação de interdependência entre emissores e receptores na construção do sentido do texto televisivo. Segundo Morley, o modo de endereçamento se caracteriza pela relação que o programa propõe para ou em conjunto com a sua audiência: "O conceito de 'modo de endereçamento' designa as específicas formas e práticas comunicativas que constituem o programa, o que teria referência dentro da crítica literária como o seu ‘tom' ou o seu 'estilo'" (MORLEY \& BRUNSDON, 1999, p.262).

Daniel Chandler chama a atenção para o fato de que a relação do nosso olhar com as imagens - pintura, fotografia, cinema, televisão - é social e historicamente construída. O modo de ver é uma construção. Recuperando a história da pintura, o autor nos lembra que a perspectiva linear, no Renascimento, constituiu um novo modo de olhar e, logo, um modo mais socialmente aceito de representar a verdade. A perspectiva é um código pictórico que apenas nos aparece como "natural" em razão de estarmos social e historicamente acostumados a "ler" as imagens de acordo com ele. E esse código nos posiciona fisicamente de um determinado modo em relação às imagens: "o código renascentista de uma perspectiva centralizada em um ponto de vista linear não é simplesmente uma técnica para indicar profundidade e relativa distância num meio bi-dimensional. É um código pictórico que reflete o crescente humanismo daquele período, apresentando imagens de um ponto de vista visual singular, subjetivo, individual e único". E mais, a perspectiva nos preparou para a câmera fotográfica: como disse McLuhan (1970), a fotografia é a mecanização da pintura em perspectiva.

Daniel Chandler destaca a relação que o texto constrói com o espectador e associa ao modo de endereçamento aspectos sociais, ideológicos e textuais. São fatores relacionados ao modo de endereçamento o contexto textual, que inclui as convenções de gênero e a estrutura sintagmática, o contexto social, que diz da presença/ausência do produtor do texto, da composição da audiência, de fatores 
institucionais e econômicos, e os constrangimentos tecnológicos, que se referem às características de cada meio.

Assim, entendemos que o modo de endereçamento depende de, se estrutura a partir das características de cada meio, tanto no que se refere ao suporte quanto às formas culturais (WILLIAMS, 1997) adquiridas por cada meio em sociedades particulares. Nessa perspectiva, por exemplo, a televisão difere do cinema em termos de suas possibilidades técnicas, de seus recursos de linguagem, dos gêneros adotados, da relação estabelecida com o público numa perspectiva histórica, das convenções que regulam as expectativas da audiência para cada um dos meios.

Analisando programas jornalísticos televisivos, John Hartley partilha a concepção de que modo de endereçamento se relaciona à construção de uma imagem da audiência: “o modo de endereçamento parece bastante próximo das pressuposições sobre quem e o que a audiência é. Estas pressuposições requerem a construção de uma imagem da audiência para quem o jornalista trabalha cotidianamente" (cf. 2001, p. 93). Sua argumentação e os procedimentos de análise que adota enfatizam a linguagem empregada pelo programa, sua estrutura narrativa e argumentativa.

$\mathrm{Na}$ nossa abordagem, o conceito de modo de endereçamento, quando aplicado aos estudos de jornalismo, nos leva a tomar como pressuposto que quem quer que produza uma notícia deverá ter em conta não apenas uma orientação em relação ao acontecimento, mas também uma orientação em relação ao receptor. Esta “orientação para o receptor" é o modo de endereçamento e é ele, em boa medida, que provê grande parte do apelo de um programa para os telespectadores (cf. HARTLEY, 2001, p. 88). O modo de endereçamento, em Hartley, se refere ao tom de um telejornal, àquilo que o distingue dos demais e nessa perspectiva, portanto, o conceito nos leva não apenas à imagem da audiência, mas ao estilo, às especificidades de um determinado programa.

Aqui, portanto, adotamos o conceito de modo de endereçamento naquilo que ele nos diz, duplamente, da orientação de um programa para o seu receptor e de um modo de dizer específico; da relação de interdependência entre emissores e receptores na construção do sentido de um produto televisivo e do seu estilo. Nessa 
perspectiva, o conceito de modo de endereçamento se refere ao modo como um determinado programa se relaciona com sua audiência a partir da construção de um estilo, que o identifica e que o diferencia dos demais. Ele permite verificar como instituição social e forma cultural se atualizam num programa específico.

No esforço de construir uma metodologia de análise do telejornalismo, temos buscado a articulação entre estrutura de sentimento, gênero televisivo e modo de endereçamento. A associação entre esses conceitos pode se mostrar uma boa base conceitual e metodológica para análise e crítica do telejornalismo porque nos permite considerar o telejornalismo, a um só tempo, uma instituição social e uma forma cultural e, portanto, proceder a uma análise que faculte a consideração de um produto midiático a partir da sua vinculação com a história e com o contexto, sem abrir mão da análise concreta dos programas. É nesse sentido que dizemos que esses são conceitos metodológicos: seu potencial deve ser avaliado na medida mesmo em que eles se prestem à análise dos produtos midiáticos concretos.

\section{Os operadores de análise dos modos de endereçamento}

A análise de programas jornalísticos televisivos, como parece óbvio, deve considerar os elementos que configuram os dispositivos propriamente semióticos da TV, os recursos da linguagem televisiva - os recursos de filmagem, edição e montagem de imagem e de som empregados pelos programas jornalísticos - e os recursos propriamente verbais. A análise deve nos levar ao que é específico da linguagem televisiva, tal como construída num determinado programa e, conseqüentemente, tal como socialmente partilhado pela audiência. A gravação ao vivo, as simulações, bem como infográficos, mapas do tempo, vinhetas, telões e cenários virtuais formam o conjunto dos recursos que, para além de credibilidade, dão agilidade e ajudam a construir a identidade dos programas e das emissoras. A análise do texto verbal, por sua vez, deve revelar as estratégias empregadas pelos mediadores para construir as notícias, interpelar diretamente a audiência e construir credibilidade.

Nossos esforços de análise, no entanto, nos mostraram que a descrição dos elementos semióticos não é suficiente para compreender as estratégias de 
configuração dos modos de endereçamento e nos colocaram diante da necessidade de construção de operadores de análise que favoreçam a articulação dos elementos semióticos aos elementos discursivos, sociais, ideológicos, culturais e propriamente comunicacionais. É nesse sentido que desenvolvemos os operadores de análise dos modos de endereçamento, que apresentamos em seguida. Ressaltamos, no entanto, que não se trata de categorias de análise, na medida mesmo em que não são excludentes e não são exaustivos, e nem se organizam a partir de quaisquer regras externas ao programa telejornalístico objeto de análise. É o modo mesmo de configuração dos programas que dirá ao analista a partir de quais operadores um programa concreto se constrói. Os operadores se articulam entre si, não devem ser observados nem interpretados isoladamente. Ao mesmo tempo, é importante tomar em conta que o objetivo de análise não deve ser descrever ou interpretar cada um dos operadores isoladamente, mas, através dos operadores, acessar o modo de endereçamento de um programa específico: os operadores são os "lugares" para onde o analista deve olhar, não o fim último do esforço analítico. A seguir, apresentamos os operadores de análise que desenvolvemos.

1. O mediador. Programas jornalísticos televisivos contam com apresentadores ou âncoras, comentaristas, correspondentes e repórteres. Sem dúvida, em qualquer formato de programa jornalístico na televisão, o apresentador é a figura central, aquele que representa a "cara" do programa e que constrói a ligação entre o telespectador, os outros jornalistas que fazem o programa e as fontes. Assim, para compreender o modo de endereçamento, é fundamental analisar quem são os apresentadores, como se posicionam diante das câmeras e, portanto, como se posicionam para o telespectador. Mas o modo de endereçamento diz respeito também aos vínculos que cada um dos mediadores (âncoras, comentaristas, correspondentes, repórteres) estabelece com o telespectador no interior no programa e ao longo da sua história dentro do campo, à familiaridade que constrói através da veiculação diária/semanal do programa, à credibilidade que constrói no interior do campo midiático e que "carrega" para o programa, ao modo como os programas constroem a credibilidade dos seus profissionais e legitimam os papéis por eles desempenhados. A valorização do trabalho do 
repórter é considerada como uma das grandes estratégias de credibilidade dos noticiários (cf. Rezende, 2000, pg.112). A noção de performance, tal como utilizada no teatro, tem sido um importante recurso descritivo para este operador analítico. A noção põe em relevo o caráter interpretativo do desempenho dos atores, dos mediadores televisivos: o ator representa a partir de seu próprio corpo, de suas próprias características, mas ele desempenha um papel. A performance do mediador é um aspecto central dos modos de endereçamento dos programas telejornalísticos - isso se torna mais evidente em programas como Cidade Alerta e Brasil Urgente, que se organizam muito claramente a partir da competência performática de seus apresentadores, e em programas de entrevista, mas também está presente nos mais discretos telejornais. O mediador é o responsável pela predominância do verbal na televisão e, nesse sentido, temos adotado como ferramenta para observação do texto verbal dos mediadores as estratégias narrativas e argumentativas desenvolvidas, considerando os recursos retóricos e persuasivos empregados.

2. O contexto comunicativo. Este operador de análise se refere ao "contexto comunicativo" em que o programa televisivo atua, contexto que compreende tanto emissor, quanto receptor e mais as circunstâncias espaciais e temporais em que o processo comunicativo se dá. A comunicação tem lugar em um ambiente físico, social e mental partilhado. Isso pode ser melhor explicado pelo recurso à noção de instruções de uso de um texto, ou seja, aqueles princípios reguladores da comunicação - os modos como os emissores se apresentam, como representam seus receptores e como situam uns e outros em uma situação comunicativa concreta. Um telejornal sempre apresenta definições dos seus participantes, dos objetivos e dos modos de comunicar, explicitamente ('você, amigo da Rede Globo', 'para o amigo que está chegando em casa agora', 'esta é a principal notícia do dia', 'Agilidade, dinamismo e credibilidade é o que queremos trazer para você', 'você é meu parceiro, nós vamos juntos onde a notícia está) - ou 
implicitamente - através das escolhas técnicas, do cenário, da postura do apresentador ${ }^{17}$.

3. O pacto sobre o papel do jornalismo. A relação entre programa e telespectador é regulada, com uma série de acordos tácitos, por um pacto sobre o papel do jornalismo na sociedade. É esse pacto que dirá ao telespectador o que deve esperar ver no programa. Para compreensão do pacto é fundamental a análise de como o programa atualiza as premissas, valores, normas e convenções que constituem o jornalismo como instituição social de certo tipo, em outras palavras, como lida como as noções de objetividade, imparcialidade, factualidade, interesse público, responsabilidade social, liberdade de expressão e de opinião, atualidade, quarto poder, como lida com as idéias de verdade, pertinência e relevância da notícia, com quais valores-notícia de referência opera. Os recursos técnicos a serviço do jornalismo, ou seja, o modo como as emissoras lidam com as tecnologias de imagem e som colocadas a serviço do jornalismo, o modo como exibem para o telespectador o trabalho necessário para fazer a notícia são fortes componentes da credibilidade do programa e também da emissora e importante dispositivo de atribuição de autenticidade. A exibição das redações como pano de fundo para a bancada dos apresentadores na maior parte dos telejornais atuais é apenas uma dessas estratégias de construção de credibilidade e, ao mesmo tempo, de aproximação do telespectador, que se torna, assim, cúmplice do trabalho de produção jornalística. Mas as transmissões ao vivo ainda são o melhor exemplo do modo como os programas buscam o reconhecimento da autenticidade de sua cobertura por parte da audiência. Redes internacionais como a CNN e a BBC são exemplares nesse sentido. Os formatos de apresentação da notícia: nota, reportagem, entrevista, indicador, editorial, comentário, resenha, crônica, caricatura; enquete, perfil, dossiê e cronologia dão importantes pistas sobre o tipo de jornalismo realizado pelos programas e, em certa medida, deixam transparecer o investimento do programa na produção da notícia. A relação com as fontes de informação, que se referem às vozes acessadas

\footnotetext{
${ }_{17}$ Para uma análise específica do operador contexto comunicativo, aplicada a programa jornalístico, ver Gutmann. 2005b.
} 
pelo programa para a construção da notícia é outro aspecto que deve ser observado, pois diz das escolhas jornalísticas realizadas. Há dois tipos elementares de fontes nos programas jornalísticos, a autoridade / o especialista e o cidadão comum. Aqui deve ser observada a posição, o lugar de fala assegurado às fontes dentro de um programa. Na maioria dos programas brasileiros, a fonte oficial é tratada de modo a transferir sua credibilidade para o programa, através do recurso à voz autorizada. Em menor escala, temos as entrevistas duras, combativas. O cidadão comum aparece de três modos básicos nos programas jornalísticos: quando ele é afetado pelas notícias; quando ele próprio se transforma em notícia, seja nos fait divers, seja nas humanizações do relato; quando ele autentica a cobertura noticiosa e é tratado como vox populi. Os conceitos de lugar de fala (Braga, 1997) e de frame, aqui entendido como quadros narrativos construídos pelo programa para 'emoldurar' suas construções noticiosas ${ }^{18}$ têm se mostrado dispositivos analíticos úteis na identificação do pacto sobre o papel do jornalismo.

4. Organização temática. A arquitetura dessa organização implica, por parte do programa, a aposta em certos interesses e competências do telespectador. No caso dos programas de jornalismo temático, parece quase óbvio dizer que a temática é o operador de maior importância para a análise do modo de endereçamento programas esportivos, programas culturais, programas ecológicos. Nesses casos, cabe analisar como a temática é abordada e como se articula aos outros operadores de análise ${ }^{19}$. Para os telejornais, entretanto, a análise da organização temática demanda maior atenção e por vezes só pode ser compreendida através da observação do modo específico de organizar e apresentar as diversas editorias e do modo específico de construir a proximidade geográfica com sua audiência. Um telejornal pode ser local, regional, nacional ou internacional. Sem ser

\footnotetext{
${ }^{18}$ Sobre a aproximação dos conceitos de frame e de modo de endereçamento, ver Santos, 2004 e Gutmann, 2005a.

19 Para uma análise do modo de endereçamento de programas jornalísticos temáticos, ver Silva, 2005, Maia, 2005 e Gutmann, 2005 a. Em Gutmann, 2005 a, a análise da temática foi articulada ao conceito de gênero musical.
} 
temático, o telejornal pode enfatizar as editorias de economia e política, ou a de cultura e lazer, ou a de esportes.

\section{Conclusão}

Do ponto de vista da análise, o pressuposto teórico-metodológico de que o telejornalismo é uma instituição social e uma forma cultural deve ser avaliado em sua encarnação concreta num programa específico. Os conceitos de estrutura de sentimento, de gênero televisivo e de modo de endereçamento devem guiar o exame concreto do telejornalismo, considerado, no primeiro caso, com o conceito de estrutura de sentimento, a partir da relação entre elementos dominantes, residuais e emergentes; no segundo, de gênero televisivo, a partir da existência de relações sociais e históricas entre as formas que o telejornalismo assume ao longo do tempo e as sociedades em que essas formas são praticadas; no terceiro, do modo de endereçamento, a partir do modo como um programa específico se relaciona com seus telespectadores a partir da construção de um estilo e, ao fazer isso, configura e reconfigura o próprio gênero.

Ressaltamos, entretanto, que o gênero televisivo é algo da ordem da virtualidade, mas, como virtualidade, ele encontra sua realização em programas específicos e, no sentido que adotamos aqui, nos modos de endereçamento que cada programa constrói na relação com os receptores. O modo de endereçametno, por sua vez, enquanto realização do gênero televisivo, contribui para construí-lo. A tarefa do analista, nesse sentido, não é buscar na programação televisiva os exemplos de gênero, nem construir classificações e tipificações, de resto pouco úteis diante da diversificação de formatos dos programas jornalísticos televisivos, com forte hibridização, mas é a de compreender como especificidades e regularidades configuradas pelo gênero televisivo se realizam em cada programa concreto. 


\section{Referências}

ALBUQUERQUE, Afonso de. Um outro Quarto Poder. Imprensa e compromisso político no Brasil in Revista Fronteiras - estudos midiáticos, vol.1, $\mathrm{n}^{0}$ 1, dezembro de 1999;

BARATA, Marla de Miranda. Modos de Endereçamento do Telejornalismo Comunitário do Bahia Meio Dia. 2006. Trabalho de Conclusão de Curso. (Graduação em Jornalismo) - Universidade Federal da Bahia;

BARBERO, Jésus Martín. "América Latina e os anos recentes: o estudo da recepção em comunicação social" in SOUSA, Mauro Wilton de (Org.). Sujeito, o lado oculto do receptor, São Paulo: Brasiliense, 1995, 39-68;

BLUMLER, Jay \& GUREVITCH, Michael. The Crisis of Public Communication, London: Routledge, 1995;

BORJA, Janira Tripodi. Qualidade e modos de endereçamento no Balanço Geral e Jogo Aberto, Salvador, Facom/UFBA, 2005, (Trabalho de Conclusão do Curso de Jornalismo);

BRAGA, José Luiz. 'Lugar de fala' como conceito metodológico no estudo de produtos culturais e outras falas in FAUSTO NETO, Antonio \& PINTO, Milton (Orgs.) Mídia e Cultura, Rio de Janeiro, Diadorim/Compôs, 1997, p. 105-120;

CHANDLER, Daniel. Semiotics for Beginners Disponível em www.aber.ac.uk/media/Documents/S4B/semiotc.html, acesso em 15/o8/2003;

DAYAN, Daniel. Pour une critique des médias in Questions de Communication, 2005, no. 8, p.195-222;

DEUZE, Mark. What is journalism? Professional identity and ideology of journalists reconsidered in Journalism, London: Sage Publications, 2005, Vol. 6(4): 442-464;

DUARTE, Dannilo de Oliveira. Jornalismo Policial na televisão: gênero e modo de endereçamento dos programas Cidade Alerta, Brasil Urgente e Linha Direta. 2007. Dissertação (Mestrado em Comunicação e Cultura Contemporânea), Universidade Federal da Bahia;

FERNANDES, Jair. Modos de Endereçamento em dois programas de entrevista brasileiros. Um estudo do Roda Viva e do Gordo a Go-Go Salvador, Facom/UFBA, 2005, (Trabalho de Conclusão do Curso de Jornalismo);

FRANCISCATO, Carlos Eduardo. A atualidade no jornalismo. Bases para sua delimitação teórica, Salvador: UFBA, 2003 (Tese de doutorado apresentada ao Programa de Pós-Graduação em Comunicação e Cultura Contemporâneas);

GOMES, Itania Maria Mota et alii. “Modo de Endereçamento no Telejornalismo do Horário Nobre Brasileiro: o Jornal Nacional, da Rede Globo de Televisão". Trabalho apresentado ao NP 07 - Comunicação Audiovisual, no XXVIII Congresso Brasileiro de Ciências da Comunicação - Intercom, Rio de Janeiro, 2005;

GOMES, Itania Maria Mota et alii. "Quem o Jornal do SBT pensa que somos? Modos de endereçamento no telejornalismo show" in Revista FAMECOS: mídia, cultura e tecnologia, Porto Alegre:Edipucrs, no. 25, dez/2004, p. 85-98;

GOMES, Itania Maria Mota. Das utilidades do conceito de modo de endereçamento para análise do telejornalismo. In Elizabeth Bastos Duarte \& Maria Lília Dias de Castro 
(Orgs.) Televisão: entre o mercado e a academia Porto Alegre: Ed. Sulina, 2006a;

GOMES, Itania Maria Mota. Telejornalismo de Qualidade. Pressupostos teóricometodológicos para análise in e-compos Revista da Associação Nacional dos Programas de Pós-Graduação em Comunicação, no. 6, ISSN: 1808-2599, agosto/2006b;

GOMES, Luana. Fantástico, O Show da Vida. Gênero e Modos de Endereçamento em programas televisivos. 2006. Trabalho de Conclusão de Curso. (Graduação em Jornalismo) - Universidade Federal da Bahia;

GOMES, Wilson da S. Esfera Pública Política e Media. Com Habermas, Contra Habermas. In RUBIM, A.; BENTZ, I.; PINTO, M. J.. (Orgs.). Produção e Recepção dos Sentidos Mediáticos, Petrópolis: Vozes, 1998, pg. 155-185.

GUERRA, Josenildo Luiz. O percurso interpretativo na produção da notícia, Salvador, UFA, 2003 (tese de doutorado apresentada ao Programa de Pós-Graduação em Comunicação e Cultura Contemporâneas da UFBA);

GUTMANN, Juliana Freire. Jornal da MTV em três versões. Gênero e modo de endereçamento como estratégias de mediação musical, Salvador, UFBA, 2005a (Dissertação de mestrado apresentada ao Programa de Pós-Graduação em Comunicação e Cultura Contemporâneas);

HALL, Stuart. Representation: cultural representation and signifying practices, London: Sage, 1997;

HARTLEY, John et alii. Conceptos clave en comunicación y estudios culturales, Buenos aires, Amorortu Editores, 1997;

HARTLEY, John. Los usos de la televisión (Trad. de Juan Trejó Álvarez), Barcelona, Paidós, 2000;

HARTLEY, John. Understanding News, London: Routledge, 2001;

JANOTTI JR, Jeder Silveira. Dos gêneros textuais, dos discursos e das canções: uma proposta de análise da música popular massiva a partir da noção de gênero midiático, Niterói, XIV Compós, 2005 (Trabalho apresentado no GT de Cultura das Mídias);

JENSEN, Klaus-Bruhn. Making sense of the news. Towards a theory and an empirical model of reception for the study of mass communication, Aarhus/Dennmark, Aarhus University Press, 1986;

MACHADO, Arlindo. A televisão levada a sério, São Paulo, Editora SENAC, 2000;

MAIA, Jussara Peixoto. O Jornal Nacional e o Globo Rural: as relações entre gêneros e modo de endereçamento no telejornalismo, Salvador, UFBA, 2005 (Dissertação de mestrado apresentada ao Programa de Pós-Graduação em Comunicação e Cultura Contemporâneas);

MORLEY, David \& BRUNSDON, Charlotte. Everyday Television: "Nationwide", London: British Film Institute, 1978;

MORLEY, David \& BRUNSDON, Charlotte. The Nationwide Television Studies, London: Routledge, 1999;

PIMENTEL, Camila Filgueiras. Modos de Endereçamento do Globo Repórter. 2006. Trabalho de Conclusão de Curso. (Graduação em Jornalismo) - Universidade Federal da Bahia; 
SAMPAIO, Adriano de Oliveira. Notícia e Cotidiano: a produção de sentido nos telejornais locais, Salvador, UFBA, 2005 (Dissertação de mestrado apresentada ao Programa de Pós-Graduação em Comunicação e Cultura Contemporâneas);

SANTOS, Luciana Silva. Enquadramento e endereçamento na editoria de política dos telejornais locais de Salvador, Salvador, UFBA, 2004 (Dissertação de mestrado apresentada ao Programa de Pós-Graduação em Comunicação e Cultura Contemporâneas);

SARLO, Beatriz. Raymond Williams, uma releitura in SARLO, Beatriz. Paisagens Imaginárias, São Paulo, Edusp, 1997, p. 85-95;

SCHUDSON, Michael. Discovering the news. A social history of american newspapers, New York: Basic Books Inc. Publishers, 1978;

SILVA, Fernanda Mauricio da. Dos telejornais aos programas esportivos: gêneros televisivos e modos de endereçamento, Salvador, UFBA, 2005 (dissertação de mestrado apresentada ao Programa de Pós-Graduação em Comunicação e Cultura Contemporâneas);

SILVA, Grasiele Vivas Mendes. Ação para quem? Uma análise dos modos de endereçamento do Programa Ação, da Rede Globo. 2005. Trabalho de Conclusão de Curso. (Graduação em Jornalismo) - Universidade Federal da Bahia, Conselho Nacional de Desenvolvimento Científico e Tecnológico;

WILLIAMS, Raymond. Cultura e Sociedade: 1780-1950 (Trad. de Leônidas H.B. Hegenberg; Octanny Silveira da Mota; e Anísio Teixeira), São Paulo: Ed. Nacional, [1958]1969;

WILLIAMS, Raymond. Marxismo e Literatura (Trad. de Waltensir Dutra), Rio de Janeiro: Jorge Zahar, [1971]1979;

WILLIAMS, Raymond. Television. Technology and Cultural Form, $2^{\text {a }}$, London: Routledge, 1997;

WILLIAMS, Raymond. The Long Revolution, Harmondsworth: Penguin, 1961. 